\title{
Linear Relationships Between Yield, Quality and Phenological Traits of Strawberry Cultivars
}

\author{
Maria Inês Diel (Corresponding author), Alessandro Dal'Col Lúcio \\ Crop Science Department, Federal University of Santa Maria, Santa Maria, RS, Brazil. \\ E-mail: mariaines.diel@hotmail.com
}

\begin{abstract}
Denise Schmidt
Agronomy Department, Federal University of Santa Maria, Frederico Westphalen, RS, Brazil.
\end{abstract}

Marcos Vinícius Marques Pinheiro

Federal University of Santa Catarina, Florianopolis, SC, Brazil.

Tiago Olivoto, Bruno Giacomini Sari, Patrícia Jesus de Melo, Francieli de Lima Tartaglia, André Luis Tischler, Darlei Michalski Lambrecht

Crop Science Department, Federal University of Santa Maria, Santa Maria, RS, Brazil.

Received: Apr. 6, 2020

doi:10.5296/jas.v8i3.16807
Accepted: May 9, 2020

Published: May 21, 2020

URL: https://doi.org/10.5296/jas.v8i3.16807

\begin{abstract}
The great economic importance attributed to strawberry cultivation raises the interest in cultivars of high productivity and superior fruit quality. The quality of fruit is the most impacting factor for the strawberry marketing, but selecting genotypes that combine high production and high fruit quality has been a difficult task. The objective of this study was to determine the linear relationships between phenological, quality and production variables of strawberry aiming at identifying potential variables for indirect selection in future selection processes of strawberry genotypes. A trial was conducted in a randomized block design with two cultivars and two transplant origins, grown in four types of substrate. Fifteen variables, including phenological, productive and fruit quality-related variables were assessed. The selected variables explained 45.2 and $39.1 \%$ for PC1 and PC2 respectively, totaling $84.3 \%$ of the total variance of the variables in the PCA, and indicated important relationships
\end{abstract}


between the variables, and a path analysis revealed success for indirect selection of total mass of fruits based on the total number of fruits (0.81413). Changes in crop management that reduces the period between planting date and full flowering may be an alternative to increase the production of strawberry and provide fruits with higher quality.

Keywords: canonical correlation, environment, Fragaria ananassa, path analysis, principal component analysis, substrates

\section{Introduction}

The production of strawberries is highly important in the commercial and social spheres. The latest data released by the Food and Agriculture Organization of the United Nations (FAOSTAT) for the year 2016, reveals an area of 401,862 hectares is cultivated around the world, producing about 911,833.6 tons of fruits of the strawberry (FAOSTAT 2019).

Since its emergence in Europe around 1750, the species Fragaria $x$ ananassa Dusch, originated from the hybridization between the American species Fragaria chiloensis and Fragaria virginiana (Hancock, 1999), has undergone several modifications over the years through genetic improvement techniques, which have been used to select variables of agronomic interest, such as characteristics of high yields and fruits with high physicochemical quality. Production, fruit quality, phenology and phylogenetic studies are important to be made available in the future for plant breeding (Diamanti et al. 2012). For example, species more resistant to water deficit have thicker leaves and cuticles, as well as greater root growth (Zhang and Archbold, 1993).

The definition of the relationship between characters in plants allows us to evaluate how much one characteristic depends or not on the other, being very important from the genetic point of view since researchers can plan actions in order to improve certain characteristics in function of others (Cruz et al. 2012). At the same time, linear relationships between characters demonstrate changes in the characteristics of a given plant/fruit during a particular management.

It is known that changes in plant management cause changes in the production and quality of what is being produced, because plant physiology is highly affected by temperature (Bisbis et al. 2018; Eyshi Rezaei et al. 2017). Plant development is temperature sensitive and therefore plant phenology can be modified when crop management modifies temperature, relative humidity, solar radiation, photoperiod, and so on (Monteiro 2009). Such modifications may be beneficial to plants or not (Bisbis et al. 2018). Research is needed in each crop in order to identify changes in management that can benefit fruit production and quality, for example.

Studies of linear relationships with strawberry have already been carried out, however, most of them use only the simple correlation analyzes, which can mask the real results. In agriculture, when studying many variables, linear regression analyzes can be used to study the patterns that follow (Guçlu et al. 2015). Moradi (2015) studied correlation and regression analysis in strawberries and found a strong correlation between fruit production and total fresh weight per plant and between sodium and copper content in the soil. With the aim of exploring environmental variation that allow a wide range of plant responses, this work aims 


\section{Macrothink}

to estimate the linear relationships between production, quality and phenology characters for strawberry cultivars grown on substrates.

\section{Material and Methods}

\subsection{Conditions for Cultivation and Preparation of the Study Area}

The cultivation was carried out in the greenhouse and the strawberry crop was cultivated in the substrate. The transplants were conditioned in $150 \mu \mathrm{m}$ white tubular plastic bags, filled with substrates and kept in benches at $0.8 \mathrm{~m}$ above the ground. Inside the bags were dripping tubes spaced $0.10 \mathrm{~m}$ apart for the fertigation and irrigation according to (Gonçalves et al. 2016). The nutrient dose for fertigation was used for substrates or irrigation water with $\mathrm{pH}$ higher than 7.0, allowing the $\mathrm{pH}$ decrease to 5.7 to 6.0 (supplemental material - S1). The electrical conductivity (EC) of the nutrient solution was $1.8 \mathrm{mS} \mathrm{cm}$ c $^{-1}$ The irrigation frequency as well as the time of each irrigation pulse were adjusted based on the solution drained from the substrate, monitoring the EC of the nutrient solution.

\subsection{Origin and Planting of Strawberry Transplants}

Two strawberry cultivars (Albion and Camarosa), coming from two origins (National and Imported) were used. The National transplants were purchased from a nursery located at the municipality of Agudo, basalt slope of Rio Grande do Sul, Brazil (29 $62^{\circ}$ ' S, 53 $22^{\circ}$ W and $83 \mathrm{~m}$ above sea level). Imported cultivars were purchased from the municipality of El Maitén, Argentina ( $42^{\circ} 3^{\prime} \mathrm{S}, 71^{\circ} 10^{\prime} \mathrm{W}$ and $720 \mathrm{~m}$ above sea level).

\subsection{Design Experimental}

The treatments consisted of the combinations of the two cultivars, the two origins of transplants and four substrates namely, crushed sugar cane residue, organic compost, burnt rice husk, commercial substrate - Carolina ${ }^{\circledR}$ (Table 2). Organic compost was purchased by composting vegetable waste, tree leaves and vegetables. Carolina commercial substrate is composed of peat, vermiculite, agroindustrial organic waste and limestone. It has a hydrogen potential $(\mathrm{pH})$ of 5.5 , electrical conductivity (EC) of $0.7 \mathrm{mS} \mathrm{cm}{ }^{-1}$ and a water retention capacity of $55 \%$. The experimental design was a randomized block design, with four replicates and eight experimental units (plants) per block. 
Table 2. Description of the 16 evaluated treatments in the experiment

\begin{tabular}{cccccccc} 
Treatment & $\begin{array}{c}\text { Crushed } \\
\text { sugar } \\
\text { cane } \\
\text { residue } \\
(\%)\end{array}$ & $\begin{array}{c}\text { Burnt } \\
\text { rice husk } \\
(\%)\end{array}$ & $\begin{array}{c}\text { Commercial } \\
\text { substrate }- \\
\text { Carolina } \\
(\%)\end{array}$ & $\begin{array}{c}\text { Organic } \\
\text { compost } \\
(\%)\end{array}$ & $\begin{array}{c}\text { Substrate } \\
\text { mix } \\
\text { name }\end{array}$ & Cultivars & $\begin{array}{c}\text { Transplants } \\
\text { origin }\end{array}$ \\
\hline 1 & 70 & 0 & 0 & 30 & $\mathrm{~S} 1$ & Albion & Imported \\
2 & 70 & 0 & 0 & 30 & $\mathrm{~S} 1$ & Albion & National \\
3 & 70 & 0 & 0 & 30 & $\mathrm{~S} 1$ & Camarosa & Imported \\
4 & 70 & 0 & 0 & 30 & $\mathrm{~S} 1$ & Camarosa & National \\
5 & 70 & 0 & 30 & 0 & $\mathrm{~S} 2$ & Albion & Imported \\
6 & 70 & 0 & 30 & 0 & $\mathrm{~S} 2$ & Albion & National \\
7 & 70 & 0 & 30 & 0 & $\mathrm{~S} 2$ & Camarosa & Imported \\
8 & 70 & 0 & 30 & 0 & $\mathrm{~S} 2$ & Camarosa & National \\
9 & 0 & 70 & 0 & 30 & $\mathrm{~S} 3$ & Albion & Imported \\
10 & 0 & 70 & 0 & 30 & $\mathrm{~S} 3$ & Albion & National \\
11 & 0 & 70 & 0 & 30 & $\mathrm{~S} 3$ & Camarosa & Imported \\
12 & 0 & 70 & 0 & 30 & $\mathrm{~S} 3$ & Camarosa & National \\
13 & 0 & 70 & 30 & 0 & $\mathrm{~S} 4$ & Albion & Imported \\
14 & 0 & 70 & 30 & 0 & $\mathrm{~S} 4$ & Albion & National \\
15 & 0 & 70 & 30 & 0 & $\mathrm{~S} 4$ & Camarosa & Imported \\
16 & 0 & 70 & 30 & 0 & $\mathrm{~S} 4$ & Camarosa & National \\
\hline
\end{tabular}

\subsection{Plant Parameters}

The phyllochron (FIL, ${ }^{\circ} \mathrm{C}$ day leaf ${ }^{-1}$ ) was estimated as the inverse of the slope of the linear regression between the number of leaves of the crown and the accumulated thermal sum (ATS). The number of days to the start flowering (NDSF) was calculated by counting the number of days from the transplant to the start of flowering (considering $50 \%$ of the plants in the block at the anthesis). The number of days for full flowering (NDFF) counting the number of days from the transplant up to the when $100 \%$ of the plants that composed the block was in anthesis, and number of days for harvest (NDH) counting the number of days from the transplant up to the beginning of the fruit harvest.

The harvests were carried out twice a week in the complete maturation stage, separating the commercial fruits from the non-commercial ones. Non-commercial fruits were those deformed or with mass less than $6.0 \mathrm{~g}$. The following variables were evaluated: Total number of fruits (TNF), total mass of fruit (TMF), Mean of fruit mass (MFM), mass of non-comercial fruits (MNCF), mass of comercial fruits (MCF).

The following fruit quality variables were evaluated: titratable acidity (TA, \% citric acid), performed by titrating with standard $\mathrm{NaOH}$ solution $\left(0.1 \mathrm{~mol} \mathrm{~L}^{-1}\right)$; total soluble solids (TSS, ${ }^{\circ}$ Brix), using manual refractometer $( \pm 2 \%$ accuracy), total soluble solids/acidity (TSS/TA), 
calculated by the quotient between the total soluble solids content and the titratable acidity; firmness (FIR), determined with a bench penetrometer with a $6.0 \mathrm{~mm}$ tip; and pulp color evaluated by chroma, hue angle and the values of $a^{*}$ and $b^{*}$. These values were determined with a colorimeter expressing the components $a^{*}$ [from red (+a) to green (-a) on the x-axis], $b^{*}$ [from yellow $(+b)$ to blue $(-b)$ on the $y$-axis], and ( $\left.b^{*} / a^{*}\right)$. The apparatus was calibrated for the $a^{*}, b^{*}$ system using the following equation: tan-1 $\left(b^{*} / a^{*}\right)$.

\subsection{Statistical Analyzes}

In order to explore the relationships between the variables, as well as the performance of the treatments regarding the variables, a biplot (Gabriel, 1971) obtained in a principal component analysis (PCA) was used made. Analyzed data was standardized to account for the different magnitude so the responses, and parameters contribute equally to the data set variance and to the principal component calculation.

Path analysis was performed from the Pearson`s correlation matrix TMF was defined as the dependent variable other ones as explanatory variables. A stepwise analysis was carried out in order to select a set of explanatory variables with minimal (acceptable) multicollinearity degree. The independent variables (explanatory), defined by stepwise, were TSS/AT, Chroma, TNF, MFM, MCF and NDH. The other variables were excluded from the analysis because they presented high multicollinearity.

After the selection of variables by Stepwise, a multicollinearity diagnosis was performed between the explanatory variables through the analysis of the condition number $C N=\frac{\lambda \text { max }}{\lambda \text { min }}$ which represents the ratio between the largest and the smallest eigenvalue of the correlation matrix, and the variance inflation factor $V I F=\frac{1}{1-R_{j}^{2}}$, where $R_{j}{ }^{2}$ is the coefficient of determination.

Path coefficients were obtained by the equation $Y=P_{o 1} X_{1}+P_{o 2} X_{2}+\ldots+P_{o n}+X_{n}+P_{u}$, where $\mathrm{Y}$ is the coefficient of the dependent variable; $\mathrm{P}_{\mathrm{o}}$ is the direct effect coefficient; $\mathrm{X}$ is an explanatory independent variable; $\mathrm{P}_{\mathrm{u}}$ is the residual effect and the standardization variable.

Aiming at identifying the relationships between the groups of variables, a canonical correlation analyzes was performed. Three groups of variables were designed namely, phenological variables (NDSF, NDFF, NDH, and FIL), production variables (MCF and MFM), and quality variables (TSS, TA, FIR, Chroma, and ${ }^{\circ} \mathrm{Hue}$ ). A multicollinearity diagnosis by VIF and CN was performed within each group of variables. For all groups, the multicollinearity was low. Then, a canonical analysis was performed for each combination of groups of variables.

Statistical analyzes were performed at $5 \%$ of significance and with the aid of packages MASS (Venables and Ripley, 2002), biotools (Silva et al. 2017) and yacca (Butts, 2018) available in R software, version 3.6.0 (R Core Team 2017). 


\section{$\triangle$ Macrothink}

\section{Results}

\subsection{Cultivation Environment}

The minimum and maximum absolute air temperature inside the protected environment registered during the evaluation period were 0.6 and $46.4^{\circ} \mathrm{C}$, respectively. The average temperature had peaks greater than $20-25^{\circ} \mathrm{C}$, but for most of the cycle, it remained between 20 and $25^{\circ} \mathrm{C}$ (Figure 1A). With respect to photosynthetically active solar radiation, which the average value remained above $12 \mathrm{MJ} \mathrm{m}^{-2}$ (Figure 1B).

A)

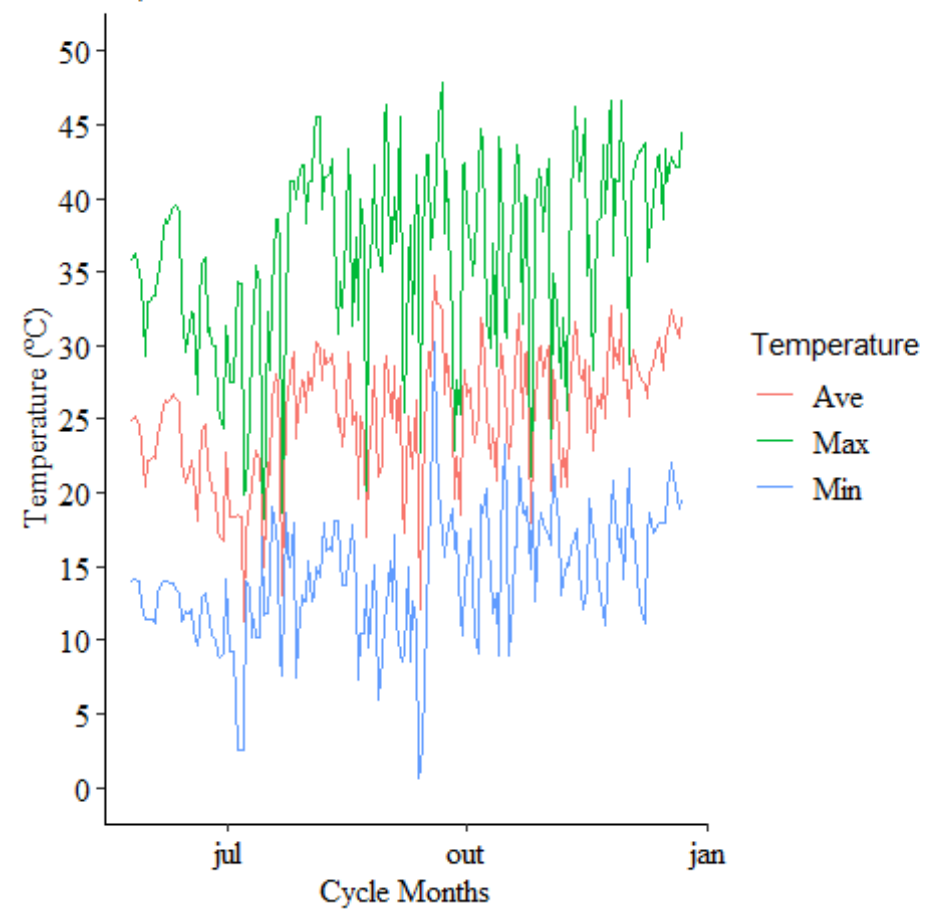

B)

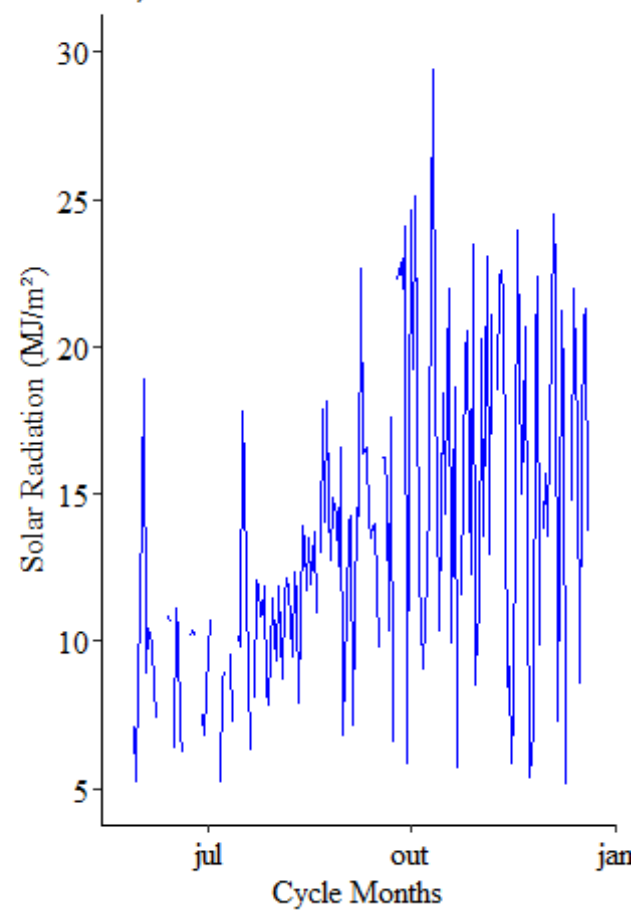

Figure 1. Maximum temperature (Max), minimum temperature (Min) and average temperature (Ave) air temperatures (A) and solar radiation (B) recorded inside the greenhouse during the production cycle

\subsection{Principal Components Analysis}

The variables that contributed the most to explain the variability in the PC1 and PC2 were TNF, MCF, NDH, NDFF, MCF, NDSF, TSS, TA and FIL, the other variables do not correlate with any PC or present low contribution and were removed to simplify the analysis (Figure 2 and table 1). 


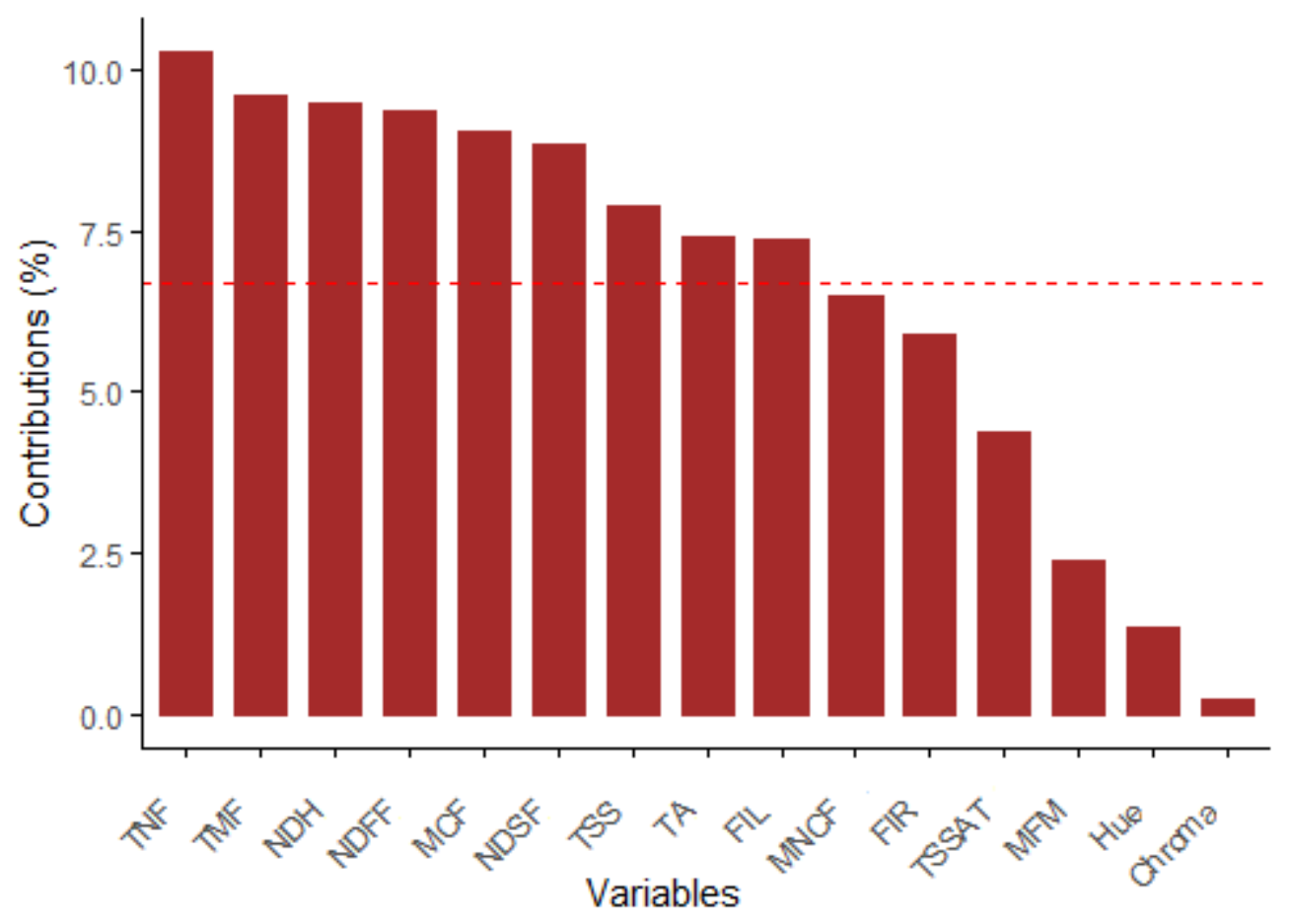

Figure 2. Contribution (\%) of the variables on the two components in the analysis of main components for production, quality and phenology data of strawberry cultivars grown on organic substrates. The red dashed line means the cutoff point. Total number of fruits (TNF), total mass of fruit (TMF), number of days for harvest (NDH), number of days for full flowering (NDFF), mass of comercial fruits (MCF), number of days to the start flowering

(NDSF), total soluble solids (TSS), titratable acidity (TA), phyllochron (FIL), mass of non-comercial fruits (MNCF), firmness (FIR), total soluble solids/acidity (TSS/TA), mean of fruit mass (MFM), chroma and hue angle (Hue). 
Table 1. Contribution of variables in each principal component (PC)

\begin{tabular}{|c|c|c|c|c|c|}
\hline Variables & PC 1 & $\mathrm{PC} 2$ & PC 3 & $\mathrm{PC} 4$ & PC 5 \\
\hline TA & 12.5452 & 0.741905 & 0.943499 & $1.96 \mathrm{E}+01$ & 0.041502 \\
\hline TSS & 12.29046 & 2.179469 & 2.112898 & $2.73 \mathrm{E}-04$ & 10.01658 \\
\hline TSSAT & 7.690548 & 0.123737 & 2.408761 & $3.58 \mathrm{E}+01$ & 5.815893 \\
\hline FIR & 5.753105 & 6.080115 & 0.737156 & $5.64 \mathrm{E}+00$ & 1.736807 \\
\hline Chroma & 0.336982 & 0.102219 & 25.46628 & $1.51 \mathrm{E}+00$ & 49.81633 \\
\hline Hue & 1.096954 & 1.655252 & 20.36098 & $8.44 \mathrm{E}+00$ & 17.81433 \\
\hline TNF & 12.9986 & 6.726612 & 0.030662 & $1.97 \mathrm{E}+00$ & 0.103542 \\
\hline $\mathrm{TMF}$ & 9.534081 & 9.657714 & 1.723063 & 4.32E+00 & 0.545976 \\
\hline MFM & 3.227371 & 1.29754 & 26.36087 & $6.39 \mathrm{E}+00$ & 1.676253 \\
\hline $\mathrm{MNCF}$ & 9.32494 & 2.819424 & 9.45674 & $4.06 \mathrm{E}+00$ & 6.644697 \\
\hline $\mathrm{MCF}$ & 8.344361 & 9.957178 & 3.901413 & $3.80 \mathrm{E}+00$ & 1.542736 \\
\hline NDSF & 2.481294 & 17.10515 & 1.225858 & $1.96 \mathrm{E}+00$ & 0.525476 \\
\hline NDFF & 2.574216 & 18.186 & 0.757739 & $1.16 \mathrm{E}-02$ & 2.781323 \\
\hline $\mathrm{NDH}$ & 4.562791 & 15.86237 & 0.462158 & $5.10 \mathrm{E}+00$ & 0.473292 \\
\hline FIL & 7.239103 & 7.505309 & 4.051927 & $1.35 \mathrm{E}+00$ & 0.465266 \\
\hline
\end{tabular}

The selected variables explained 45.2 and $39.1 \%$ for PC1 and PC2 respectively, totaling $84.3 \%$ of the total variance of the variables (Figure 3 ). The variables that TA and TSS correlate positively, that is, fruits with higher TSS content also have a high TA content. This causes a balance in the ratio TSS/TA. At the same time, it can be concluded that these variables are negatively correlated with the others, mainly with NDSF and NDH, inferring that when the beginning of the reproductive period occurs late the fruits tend to present less TSS and TA. There is no correlation between FIL with TA and TSS (Figure 3). 


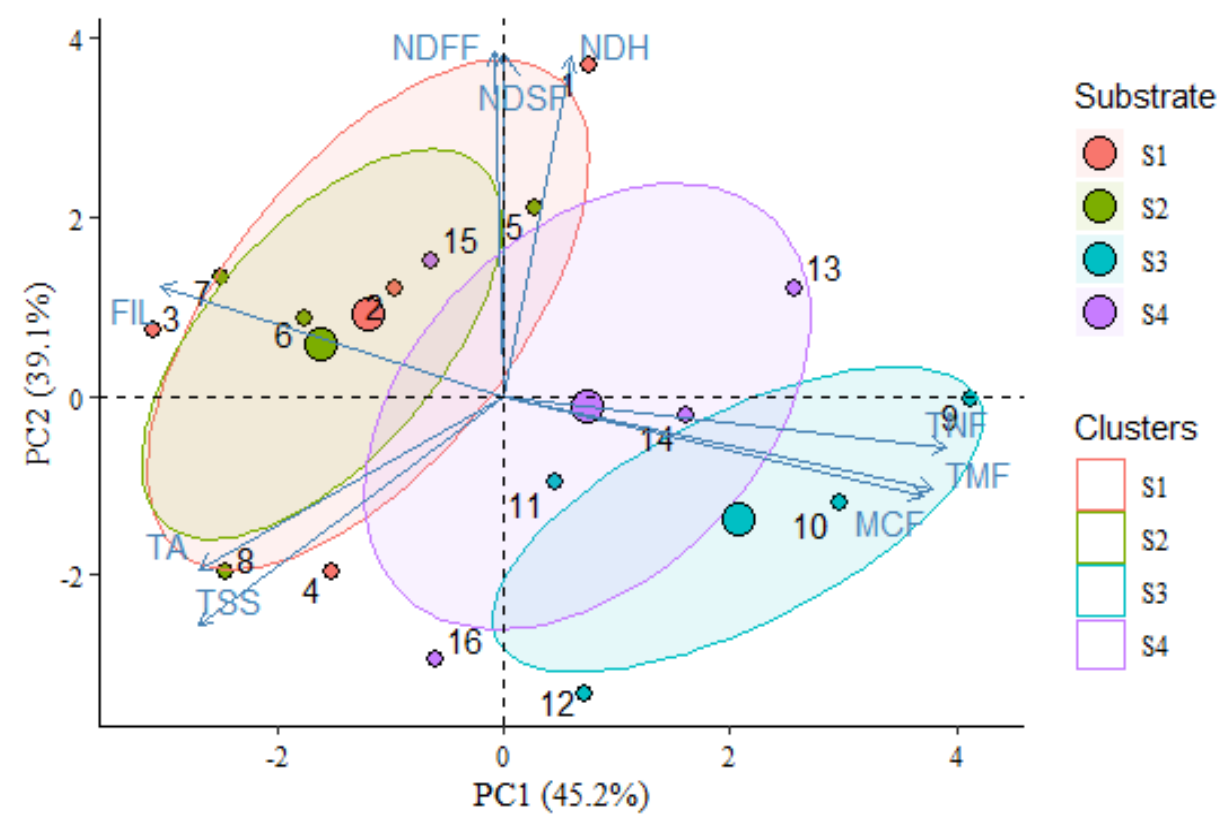

Figure 3. Biplot for phenology data, production and quality of strawberry fruits grown on substrates (IPCA1 x IPCA2)

Phyllochron (FIL) number of days to the start flowering (NDSF), number of days for full flowering (NDFF), number of days for harvest (NDH), Total number of fruits (TNF), total mass of fruit (TMF), mass of comercial fruits (MCF), titratable acidity (TA), total soluble solids (TSS),

It can be verified the high positive correlation between the fruit production variables MCF, TMF and TNF, since they formed an acute angle between them (Figure 3). These relationships were already expected because the number of fruits will result in the mass of the fruits, whether these are commercial or not. There is a negative correlation between FIL with TNF, TMF and MCF, evidencing the influence of leaf emission on the production of strawberry fruits, the faster the leaf emission (the smaller the phyllochron, more leaves the plant emits) the greater the interception of solar radiation transformed into photoassimilated for the plant to convert into fruit production.

In relation to productivity, we can see that higher MCF, TNF and TMF were produced by the plants grown on the substrate S3 (burnt rice husk + organic compost), that is, this mixture of substrate presents the physical characteristics for plant development (density, total porosity, aeration space, readily available water, buffer water, available water, remaining water) (Supplemental material SM 2). In relation to productivity, we can see that higher MCF, TNF and TMF were produced by the plants grown on the substrate S3 (burnt rice husk + organic compost), that is, this mixture of substrate presents the physical characteristics for plant development.

The grouping created by the PCA indicates the separation of the variables by the substrate used in the cultivation, and reveals the approximation and similarity between the substrates 
$\mathrm{S} 1$ and S2. The S4 presented intermediate, guaranteed higher production compared to S1 and S2. The result indicates S3 as best for strawberry cultivation on substrate.

\subsection{Path Analysis}

The independent variables (explanatory), defined by stepwise, were TSS/TA, Chroma, TNF, MFM, MCF, and NDH, resulting in low CN and VIF (Table 3). The other variables were excluded from the analysis because they presented high multicollinearity.

Table 3. Path analysis between the main dependent variable - direct effect (diagonal) mass of total fruits (TMF), and explanatory variables (indirect effects) total fruit number (TNF), average fruit mass (MMF), total soluble solids/total titratable acidity ratio (TSS/TA), Chroma, and number of days for harvest (NDH) and mass of comercial fruits (MCF) of strawberries grown on substrates

\begin{tabular}{|c|c|c|c|c|c|c|c|}
\hline Character & TSS/TA & Chroma & TNF & MMF & MCF & $\mathrm{NDH}$ & $\mathrm{r}$ \\
\hline TSS/TA & -0.01054 & 0.00252 & 0.15278 & -0.01394 & 0.01921 & -0.00209 & 0.15 \\
\hline Chroma & 0.00115 & -0.02321 & -0.04354 & -0.03923 & -0.02060 & 0.00191 & -0.12 \\
\hline TNF & -0.00198 & 0.00124 & 0.81413 & -0.02661 & 0.16159 & 0.00203 & 0.95 \\
\hline MMF & 0.00066 & 0.00411 & -0.09770 & 0.22171 & 0.04644 & 0.00266 & 0.18 \\
\hline $\mathrm{MCF}$ & -0.00111 & 0.00261 & 0.71813 & 0.05621 & 0.18319 & 0.00316 & 0.96 \\
\hline $\mathrm{NDH}$ & -0.00132 & 0.00266 & -0.09917 & -0.03544 & -0.03470 & -0.01666 & -0.18 \\
\hline VIF $^{*}$ & 1.09 & 1.07 & 10.90 & 2.56 & 11.29 & 1.10 & \\
\hline $\mathrm{CN}$ & 46.34 & & & & & & \\
\hline R-squared & 0.99 & & & & & & \\
\hline Residual effect & 0.08 & & & & & & \\
\hline
\end{tabular}

*VIF: variance inflation factor, $\mathrm{CN}$ : condition number

The variables TSS/TA, Chroma, MFM and NDH do not have a cause and effect relationship with the TMF because the correlations are negligible. For the MCF variable, which presented a positive and high Pearson correlation coefficient and a negligible direct effect, due to the indirect effects via TNF. For TNF, a high positive and the direct was observed, indicating that TMF is fully explained by the TNF variable; that is, there is it a cause and effect relationship between these two variables (Table 3). 


\subsection{Canonical Correlation Analysis}

The multicollinearity diagnosis within each group of variables was low. The analysis of canonical correlations was first interpreted using the level of significance of the canonical correlation. If not significant, the magnitude of the canonical correlation was considered.

The canonical correlations between phenological and quality characters presented the first pair of the canonical correlation significant $(r=0.61, p=0.003)$, demonstrating that these groups are dependent and that their coefficients can be used to study the characters of these group. The canonical cross-loadings of the TSS and TA characters with high magnitudes, however for the phenological characters the canonical cross-loadings were low, but it can be inferred that the increase in NDSF decreases the content of TSS and TA (Table 4).

Table 4. Correlations and canonical cross- landings the between the group of phenological variables number of days to the start flowering (NDSF), number of days for full flowering (NDFF), number of days for harvest (NDH) and phyllochron (FIL), and group of quality variables total titratable acidity (AT), total soluble solids (TSS), firmness (FIR), Chroma and Hue angle (Hue)

\begin{tabular}{|c|c|c|c|c|}
\hline \multirow{2}{*}{ Characters } & \multicolumn{4}{|c|}{ Canonical cross- landings } \\
\hline & $1^{\mathrm{o}}$ & $2^{\circ}$ & $3^{\circ}$ & $4^{\mathrm{a}}$ \\
\hline \multicolumn{5}{|c|}{ Phenological variables } \\
\hline NDSF & 0.33 & -0.18 & -0.16 & 0.03 \\
\hline NDFF & 0.38 & 0.13 & -0.14 & 0.05 \\
\hline $\mathrm{NDH}$ & 0.40 & -0.12 & -0.04 & 0.09 \\
\hline FIL & -0.41 & -0.01 & -0.11 & 0.08 \\
\hline \multicolumn{5}{|c|}{ Quality variables } \\
\hline TA & -0.42 & 0.13 & 0.02 & 0.04 \\
\hline TSS & -0.45 & 0.19 & 0.08 & 0.01 \\
\hline FIR & -0.21 & -0.16 & 0.07 & -0.10 \\
\hline Chroma & 0.03 & 0.28 & -0.04 & -0.09 \\
\hline${ }^{\circ} \mathrm{Hue}$ & -0.29 & -0.15 & -0.17 & 0.01 \\
\hline Canonical correlations $r$ & $0.61 *$ & 0.41 & 0.24 & 0.13 \\
\hline$\chi^{2}$ & 42.05 & 14.73 & 4.33 & 1.03 \\
\hline Degrees of freedom & 20 & 12 & 6 & 2 \\
\hline p-valor & 0.003 & 0.257 & 0.632 & NA \\
\hline
\end{tabular}


The canonical correlations between yield and phenological characters presented the first pair of the canonical correlation significant $(r=0.42, p=0.0173)$, demonstrating that these groups are dependent. The higher MFM occurs when there is a shorter period for the plants to come into full flowering since NDFF obtained $r=0.14$ (Table 5).

Table 5. Correlations and canonical cross- landings the between the group of phenological variables number of days to the start flowering (NDSF), number of days for full flowering (NDFF), number of days for harvest (NDH) and phyllochron (FIL), and group of production variables mean fruit mass (MMF, g), mass of commercial fruits (MCF, g plant ${ }^{-1}$ )

\begin{tabular}{|c|c|c|}
\hline \multirow{2}{*}{ Characters } & \multicolumn{2}{|c|}{ Canonical cross-loadings } \\
\hline & $1^{\mathrm{o}}$ & $2^{\mathrm{o}}$ \\
\hline \multicolumn{3}{|c|}{ Production variables } \\
\hline MMF & -0.35 & 0.19 \\
\hline $\mathrm{MCF}$ & 0.14 & 0.31 \\
\hline \multicolumn{3}{|c|}{ Phenological variables } \\
\hline NDSF & 0.02 & -0.20 \\
\hline NDFF & 0.14 & -0.31 \\
\hline $\mathrm{NDH}$ & 0.04 & -0.22 \\
\hline FIL & 0.40 & -0.14 \\
\hline Canonical correlations $r$ & $0.42 *$ & 0.33 \\
\hline$\chi^{2}$ & 18.58 & 6.95 \\
\hline Degrees of fredom & 8.00 & 3.00 \\
\hline $\mathrm{p}$-valor & 0.0173 & 0.0735 \\
\hline
\end{tabular}

The canonical correlations between productive and fruit quality variables presented a non-significant canonical correlation, revealing the linear independence between the groups. This suggests that it is not possible to select qualitative variables based on the productive variables in strawberry (Table 6). 


\section{Ml Macrothink}

Table 6. Correlations and canonical cross- landings the between the group of production variables mean fruit mass (MFM, g) and mass of commercial fruits $\left(\mathrm{MCF}, \mathrm{g}\right.$ plant $\left.^{-1}\right)$, and group of production quality variables total titratable acidity (AT), total soluble solids (SST), firmness (FIR), Chroma and Hue angle ( $\left.{ }^{\circ} \mathrm{Hue}\right)$

\begin{tabular}{ccc}
\hline & \multicolumn{2}{c}{ Canonical cross-loadings } \\
\cline { 2 - 3 } Characters & $1^{\mathrm{o}}$ & $2^{\mathrm{o}}$ \\
\hline MMF & \multicolumn{2}{c}{ Production variables } \\
\hline MCF & -0.33 & 0.14 \\
\hline TA & \multicolumn{2}{c}{ Quality variables } \\
\hline TSS & 0.24 & -0.16 \\
FIR & 0.26 & -0.15 \\
Chroma & 0.08 & 0.08 \\
${ }^{\circ}$ Hue & -0.11 & -0.15 \\
& 0.23 & 0.15 \\
\hline Canonical correlations $r$ & 0.38 & 0.27 \\
$\chi^{2}$ & 14.30 & 4.59 \\
Degrees of fredom & 10.00 & 4.00 \\
p-valor & 0.15 & 0.33 \\
\hline
\end{tabular}

\section{Discussion}

The PCA is interesting when it is intended to explain the differentiation between treatments and to obtain more information about the variables that mainly influence the similarities and differences in the treatments (Šamec et al. 2016a). Several studies used PCA in a strawberry study (Kårlund et al. 2016; Šamec et al. 2016a; Urrutia et al. 2017; Vendel et al. 2019). E It was observed important relations that can be used as information for future management studies of the strawberry crop, besides guiding studies of genetic breeding. The significant and positive relationship between TA and TSS, since the fruit's flavor is determined by both variables and should be taken into account with a view to the production of high-taste fruit, by designating them to in natura consumption or for industry; because the market demands high organoleptic quality fruits (Šamec et al. 2016).

The fruit flavor is determined by the acid content, total soluble solids, and their ratio, and this can be modified by the type of production system used (Krüger et al. 2012). In addition, these characteristics are controlled by a complex genetic background, being associated with negative agronomic traits, such as lower fruit firmness, fruit size or productivity (Di Vittori et al. 2018). 
The results obtained between the NDSF and NDH variables with the TSS variable reveal that the lower the period for the plants to undergo flowering and fruit formation, the higher the TSS content. This result is related to the ideal temperature in the growing site (Rahman et al. 2014), because at the same time it favors the early flowering, it stimulates the production of TSS in the fruits. That is, the higher TSS content can be explained due to favorable temperature and humidity during the period of fruit growth, especially at night (Sharma and Sharma, 2006), which influenced the retention of higher TSS in mature fruits.

The other variables of fruit quality did not present linear relations (FIR, Chroma and ${ }^{\circ} \mathrm{Hue}$ ), indicating that they have no dependence on any other variable of interest. These variables are important for the definition of texture and color of fruits.

Fruit color is determined by genotype, but also highly influenced by environmental conditions and maturation stage (Di Vittori et al. 2018) being that the acceptance of the fruits by the consumers is influenced by these variables that identify the attractive color and texture of the fruits (Ornelas-Paz et al. 2013). In this way, new studies are necessary to identify what actions are necessary so that these attributes can be improved, because, in addition to agronomic attributes of production, sensorial characteristics of fruits have an increasing priority in many breeding programs (Di Vittori et al. 2018). In this study, we can indicate the factors related to the cultivation system used influencing the quality of the fruits

In the present study, TNF, TMF and MCF production characters had a negative correlation with FIL, indicating that the lower the phyllochron the higher the fruit production, this result is directly related to the emission of leaves and the interception of the solar radiation transformed in photoassimilates in the plant. In a study by Lacey (1973) where a study of the phenotypic correlations between vegetative characters and yield of strawberry fruits was carried out, found that the number and size of the fruits had a significant correlation with the number of leaves, and concluded that vegetative characters can be used for selection of cultivars with high yield of fruits. In contrast Mishra et al. (2015) found no relationship between fruit yield and leaf number in strawberry plants.

Hortynski et al. (1976) also found significant correlations between the number of leaves and fruit production, and this vegetative trait is also influenced by the growing environment since the number of leaves in the plants during the winter period was correlated with the productivity in the summer. According to Singh et al. (2010) the number of leaves per plant and the weight of the fruits showed a significant and positive correlation with the production of fruits per plant.

Although correlation studies are used to determine the linear relationships that influence fruit yield and quality, they do not prove the direct and indirect effects of independent variables ( Cruz et al. 2012; Chhetri 2015). In this way, path analysis realistically direct the weight of each variable in favor of plant breeding.

Path analysis revealed a cause and effect relationship between the independent variable TNF and the dependent variable TMF. This was already expected since the total number of fruits reflects on the total mass of fruits. Ghoochani et al. (2015) evaluated the relationship between 
morphological and chemical parameters of strawberry cultivars and identified a greater direct effect of morphological parameters due to fruit weight and shorter period for flowering. The same authors observed a direct effect of the mass of the fruits, and that the period of flowering and fruiting have a direct and negative effect on the fruit production. Regarding the production parameters, these authors affirm that fruit size and mass are the characters that most contribute to yield and suggest that they are considered for indirect selection of strawberry cultivars.

Correlations analyzes are important for the researcher to identify the relationships between different groups that would not be identified with the correlations between the pairs of variable (Cruz et al. 2012). In the present study, the canonical correlations presented low multicollinearity within the groups evaluated, CN less than 100 (Montgomery and Peck, 1982) and VIF less than 10 (Hair et al. 2009). The analysis between the groups of phenological variables and fruit quality variables had the first pair of significant canonical correlation inferring that the groups have linear dependence and that can be used with the criterion for the genetic improvement. The results show that the quality characters TA, TSS be increased if the period required for the start of flowering and the beginning of the harvest is reduced. This is a relationship that is more environment-dependent than genotype-dependent ( Rahman et al. 2014; Di Vittori et al. 2018) because the crop of the strawberry needs thermal conditions, humidity and photosynthetically active radiation adequate to meet the desirable characteristics of production and quality (Hancock 1999). On the contrary, the increase in the period between the transplanting of the seedlings until the beginning of the flowering and harvesting of the fruits increases the firmness, this characteristic can be desired, because firmer fruits tend to have greater mechanical resistance, to benefit the transport and to have a longer life of shelf (Silva et al. 2015).

Phenology also had an influence on production characteristics with a negative coefficient, ie, when there is a decrease in the period for the plants to be fully flowering, the higher the average fruit mass. This factor, as with TA and TSS, is also related to the growing environment, mainly in the seedling production stage (Serçe and Hancock, 2005), because at this stage the plants produce photoassimilates and store it in the crown to be used during fruit production. When the seedlings produced the optimum amount of photoassimilates the establishment in the field is better succeeded, the plants have larger initial development and enter earlier in the reproductive period, in addition, fruit production will also be improved (Zhang and Archbold, 1993; Rahman et al. 2016).

Analyzes of canonical correlations between the groups of production variables and fruit quality suggest that larger fruits are more acidic and firmer. Toebe et al. (2016) observed the same relation for apple fruits. Thus, it is possible to infer that any increase in the biomass production of the plant alters the nutritional allocation patterns of the fruits, with direct implications on the quality (Correia et al. 2011).

The results of the analyzes suggest that the plant management help in the production of fruits with the characteristics of production and quality fruits by the phenology, that is, when directing the date of the transplant, the cultivation substrate or the environment, we can 
modify the cycle of the plant, increasing or decreasing the period for the plant to start flowering and the date of beginning of harvest. The growing environment must be chosen so that the meteorological variables are directed to the optimization of the photosynthetic processes of the plant, thus allowing the transformation of the photoassimilates into production to be more efficient. These factors cause interference in the quality and production as demonstrated by the linear relationships performed in this study.

\section{Conclusions}

There are linear relationships between phenological characters, production and fruit quality in strawberry. Actions and management that shorten the period until the beginning of the harvest are essential for the production of high-quality fruits and fruits of greater mass, because this management alters the phenology of the plant increasing the quality and average fruit mass of Strawberry.

\section{Acknowledgments}

We thank the Coordination for the Improvement of Higher Education Personnel (CAPES) and National Council for Scientific and Technological Development (CNPq) for granting the scholarships to the researchers.

\section{References}

Bisbis, M. B., Gruda, N., \& Blanke, M. (2018). Potential impacts of climate change on vegetable production and product quality - A review. Journal of Cleaner Production, 170, 1602-1620. https://doi.org/10.1016/j.jclepro.2017.09.224

Butts, C. T. (2018). yacca: Yet Another Canonical Correlation Analysis Package. Retrieved from https://cran.r-project.org/package=yacca

Chhetri, A. (2015). Studies on Genetic Divergence in Strawberry (Fragaria x ananassa Duch.). Tesis (VCSG Uttarakhand University of Horticulture and Forestry).

Correia, P. J., Pestana, M., Martinez, F., Ribeiro, E., Gama, F., Saavedra, T., \& Palencia, P. (2011). Relationships between strawberry fruit quality attributes and crop load. Scientia Horticulturae, 130(2), 398-403. https://doi.org/10.1016/J.SCIENTA.2011.06.039

Cruz, C. D., Regazzi, A. J., \& Carneiro, P. C. S. (2012). Modelos biométricos aplicados ao melhoramento genético (4th ed.). Viçosa: Editora UFV.

Di Vittori, L., Mazzoni, L., Battino, M., \& Mezzetti, B. (2018). Pre-harvest factors influencing the quality of berries. Scientia Horticulturae, 233(July 2017), 310-322. https://doi.org/10.1016/j.scienta.2018.01.058

Diamanti, J., Capocasa, F., Denoyes, B., Petit, A., Chartier, P., Faedi, W., ... Mezzetti, B. (2012). Standardized method for evaluation of strawberry (Fragaria $\times$ ananassa Duch.) germplasm collections as a genetic resource for fruit nutritional compounds. Journal of Food Composition and Analysis, 28(2), 170-178. https://doi.org/10.1016/J.JFCA.2012.07.007

Eyshi Rezaei, E., Siebert, S., \& Ewert, F. (2017). Climate and management interaction cause 
diverse crop phenology trends. Agricultural and Forest Meteorology, 233, 55-70. https://doi.org/10.1016/j.agrformet.2016.11.003

Faostat. (2020). FAO: Food and Agriculture Organization of the United Nations Statistics Division. Retrieved from http://www.fao.org/faostat/en/\#data/QC

Ghoochani, R., Vosough, A., \& Karami, F. (2015). Heritability , Genetic Variability and Relationship among Morphological and Chemical Parameters of Strawberry Cultivars, 7(1), 218-224.

Gonçalves, M. A., Vignolo, G. K., Antunes, L. E. C., \& Reisser Junior, C. (2016). Produção de Morango Fora do Solo. Embrapa Clima Temperado (Embrapa Cl). Pelotas.

Guçlu, S. F., Önçu, Z., \& Koyuncu, F. (2015). Bazı Sert Çekirdekli Meyve Türlerinde Çiçek Tozu Çimlenmesi ve Çim Borusu Uzunluğunun Çoklu Regresyon Yöntemi ile Modellenmesi.

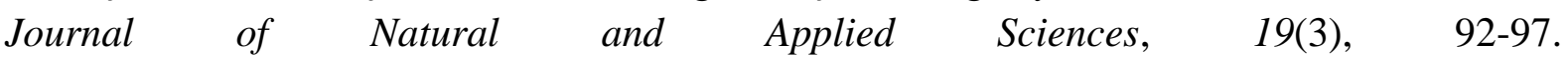
https://doi.org/10.19113/sdufbed.04496

Hair, J. F., Black, W. C., Babin, B. J., Anderson, R. E., \& Tatham, R. L. (2009). Análise multivariada de dados (6th ed.). Porto Alegre: Bookman.

Hancock, J. (1999). Strawberries (Wallingfor).

Hortynski, J., Flis, I., \& Hulewicz, T. (1976). Phenotypic correlations concerning generative and vegetative characters in the strawberry (Fragaria $x$ ananassa Duch.). Zeitschrift-FurPflanzenzuchtung, 77(2), 121-132.

Kårlund, A., Moor, U., McDougall, G., Lehtonen, M., Karjalainen, R. O., \& Hanhineva, K. (2016). Metabolic profiling discriminates between strawberry (Fragaria $\times$ ananassa Duch.) cultivars grown in Finland or Estonia. Food Research International, 89, 647-653. https://doi.org/10.1016/J.FOODRES.2016.09.013

Krüger, E., Josuttis, M., Nestby, R., Toldam-Andersen, T. B., Carlen, C., \& Mezzetti, B. (2012). Influence of growing conditions at different latitudes of Europe on strawberry growth performance, yield and quality. Journal of Berry Research, 2(3), 143-157. https://doi.org/10.3233/JBR-2012-036

Lacey, C. N. D. (1973). Phenotypic correlations between vegetative characters and yield components in strawberry. Euphytica, 22(3), 546-554. https://doi.org/10.1007/BF00036655

Mishra, P. K., Ram, R. B., \& Kumar, N. (2015). Genetic variability, heritability, and genetic advance in strawberry (Fragaria $\times$ ananassa duch.). Turkish Journal of Agriculture and Forestry, 39(3), 451-458. https://doi.org/10.3906/tar-1408-99

Monteiro, J. E. B. A. (org. . (2009). Agrometeorologia dos Cultivos: O fator meteorológico na produção agrícola. Agrometeorologia dos Cultivos: $O$ fator meteorológico na produção agrícola. Brasilia, DF: Instituto Nacional de Meteorologia - INMET.

Montgomery, D. C., \& Peck, E. A. (1982). Introduction to linear regression analysis. New York: John Wiley \& Sons, Ltd. 
Moradi, S. (2015). Study of Correlation and Regression Analysis in Strawberry. International Journal of Farming and Allied Sciences, 4(8), 621-624.

Ornelas-Paz, J. D. J., Yahia, E. M., Ramirez-Bustamante, N., Perez-Martinez, J. D., Escalante-Minakata, M. D. P., Ibarra-Junquera, V., ... Ochoa-Reyes, E. (2013). Physical attributes and chemical composition of organic strawberry fruit (Fragaria $\mathrm{x}$ ananassa Duch, Cv. Albion) at six stages of ripening. Food Chemistry. https://doi.org/10.1016/j.foodchem.2012.11.006

R Core Team. (2019). R: A language and environment for statistical computing. R Foundation for Statistical Computing. Vienna, Austria. Retrieved from https://www.r-project.org/

Rahman, M. M., Moniruzzaman, M., Ahmad, M. R., Sarker, B. C., \& Khurshid Alam, M. (2016). Maturity stages affect the postharvest quality and shelf-life of fruits of strawberry genotypes growing in subtropical regions. Journal of the Saudi Society of Agricultural Sciences, 15(1), 28-37. https://doi.org/10.1016/j.jssas.2014.05.002

Rahman, M. M., Rahman, M. M., Hossain, M. M., Khaliq, Q. A., \& Moniruzzaman, M. (2014). Effect of planting time and genotypes growth, yield and quality of strawberry (Fragariaxananassa Duch.). Scientia Horticulturae, 167, 56-62. https://doi.org/10.1016/j.scienta.2013.12.027

Šamec, D., Maretić, M., Lugarić, I., Mešić, A., Salopek-Sondi, B., \& Duralija, B. (2016a). Assessment of the differences in the physical, chemical and phytochemical properties of four strawberry cultivars using principal component analysis. Food Chemistry, 194, 828-834. https://doi.org/10.1016/J.FOODCHEM.2015.08.095

Šamec, D., Maretić, M., Lugarić, I., Mešić, A., Salopek-Sondi, B., \& Duralija, B. (2016b). Assessment of the differences in the physical, chemical and phytochemical properties of four strawberry cultivars using principal component analysis. Food Chemistry, 194, 828-834. https://doi.org/10.1016/J.FOODCHEM.2015.08.095

Serçe, S., \& Hancock, J. F. (2005). The temperature and photoperiod regulation of flowering and runnering in the strawberries, Fragaria chiloensis, F. virginiana, and F. x ananassa. Scientia Horticulturae, 103(2), 167-177. https://doi.org/10.1016/j.scienta.2004.04.017

Sharma, G., \& Sharma, O. C. (2006). Correlation and Path analysis in strawberry (Fragaria x ananassa Duch). The Horticulture Journal, 19(1), 1-4.

Silva, A. R., Malafaia, G., \& Menezes, I. p. (2017). Biotools: an R function to predict spatial gene diversity via an individual-based approach. Genetics and Molecular Research, 16(2), 1-6. https://doi.org/10.4238/gmr16029655

Silva, M. S., Dias, M. S. C., \& Pacheco, D. D. (2015). Desempenho produtivo e qualidade de frutos de morangueiros produzidos no norte de Minas Gerais. Horticultura Brasileira, 33, 251-256.

Singh, S. R., Sundouri, A. S., Sharma, M. K., \& Srivastva, K. K. (2010). Correlation and path analysis of yield and its components in strawberry (Fragaria $\mathrm{x}$ ananassa Duch.). Indian 
Journal of Plant Genetic Resources, 23(2), 239-242.

Toebe, M., Both, V., Thewes, F. R., Filho, A. C., \& Brackmann, A. (2016). Relações lineares entre caracteres de frutos de maçã. Bragantia, 75(4), 396-400.

Urrutia, M., Rambla, J. L., Alexiou, K. G., Granell, A., \& Monfort, A. (2017). Genetic analysis of the wild strawberry (Fragaria vesca) volatile composition. Plant Physiology and Biochemistry, 121, 99-117. https://doi.org/10.1016/J.PLAPHY.2017.10.015

Venables, W. N., \& Ripley, B. D. (2002). Modern Applied Statistics with S. Fourth Edition. (Springer, Ed.). New York.

Vendel, I., Hertog, M., \& Nicolaï, B. (2019). Fast analysis of strawberry aroma using SIFT-MS: A new technique in postharvest research. Postharvest Biology and Technology, 152, 127-138. https://doi.org/10.1016/J.POSTHARVBIO.2019.03.007

Wright, S. (1921). Correlation and Causation. Journal of Agricultural Research. https://doi.org/10.2307/3966855

Zhang, B., \& Archbold, D. D. (1993). Solute Accumulation in Leaves of a Fragaria chiloensis and a F. virginiana Selection Responds to Water Deficit Stress. J. Amer. Soc. Hort. Sci., $118(2), 280-285$.

\section{Copyright Disclaimer}

Copyright for this article is retained by the author(s), with first publication rights granted to the journal.

This is an open-access article distributed under the terms and conditions of the Creative Commons Attribution license (http://creativecommons.org/licenses/by/4.0/). 